\title{
Front Matter: Volume 10403
}

, "Front Matter: Volume 10403," Proc. SPIE 10403, Infrared Remote Sensing and Instrumentation XXV, 1040301 (10 November 2017); doi:

$10.1117 / 12.2295837$

SPIE Event: SPIE Optical Engineering + Applications, 2017, San Diego, California, United States 


\section{PROCEEDINGS OF SPIE}

\section{Infrared Remote Sensing and Instrumentation XXV}

Marija Strojnik

Maureen S. Kirk

Editors

7-8 August 2017

San Diego, California, United States

Sponsored and Published by

SPIE 
The papers in this volume were part of the technical conference cited on the cover and title page. Papers were selected and subject to review by the editors and conference program committee. Some conference presentations may not be available for publication. Additional papers and presentation recordings may be available online in the SPIE Digital Library at SPIEDigitalLibrary.org.

The papers reflect the work and thoughts of the authors and are published herein as submitted. The publisher is not responsible for the validity of the information or for any outcomes resulting from reliance thereon.

Please use the following format to cite material from these proceedings:

Author(s), "Title of Paper," in Infrared Remote Sensing and Instrumentation XXV, edited by Marija Strojnik, Maureen S. Kirk, Proceedings of SPIE Vol. 10403 (SPIE, Bellingham, WA, 2017) Sevendigit Article CID Number.

ISSN: 0277-786X

ISSN: 1996-756X (electronic)

ISBN: 9781510612631

ISBN: 9781510612648 (electronic)

Published by

SPIE

P.O. Box 10, Bellingham, Washington 98227-0010 USA

Telephone +1 3606763290 (Pacific Time) · Fax +1 3606471445

SPIE.org

Copyright (c) 2017, Society of Photo-Optical Instrumentation Engineers.

Copying of material in this book for internal or personal use, or for the internal or personal use of specific clients, beyond the fair use provisions granted by the U.S. Copyright Law is authorized by SPIE subject to payment of copying fees. The Transactional Reporting Service base fee for this volume is $\$ 18.00$ per article (or portion thereof), which should be paid directly to the Copyright Clearance Center (CCC), 222 Rosewood Drive, Danvers, MA 01923. Payment may also be made electronically through CCC Online at copyright.com. Other copying for republication, resale, advertising or promotion, or any form of systematic or multiple reproduction of any material in this book is prohibited except with permission in writing from the publisher. The CCC fee code is 0277$786 \mathrm{X} / 17 / \$ 18.00$.

Printed in the United States of America.

Publication of record for individual papers is online in the SPIE Digital Library.

\section{SPIE. DIGITAL}

Paper Numbering: Proceedings of SPIE follow an e-First publication model. A unique citation identifier (CID) number is assigned to each article at the time of publication. Utilization of CIDs allows articles to be fully citable as soon as they are published online, and connects the same identifier to all online and print versions of the publication. SPIE uses a seven-digit CID article numbering system structured as follows:

- The first five digits correspond to the SPIE volume number.

- The last two digits indicate publication order within the volume using a Base 36 numbering system employing both numerals and letters. These two-number sets start with $00,01,02,03$, 04, 05, 06, 07, 08, 09, OA, OB ... 0Z, followed by 10-1Z, 20-2Z, etc. The CID Number appears on each page of the manuscript. 


\title{
Contents
}

\author{
vii Authors \\ ix Conference Committee \\ xi Introduction
}

SESSION 1 EMERGING INFRARED TECHNOLOGIES

1040303 Research on active imaging information transmission technology of satellite borne quantum remote sensing [10403-2]

\section{SESSION $2 \quad$ MID IR SOURCES AND DETECTORS}

1040305 Long wavelength interband cascade lasers on GaSb substrates (Invited Paper) [10403-4]

1040306 Antimonide-based resonant tunneling photodetectors for mid-infrared wavelength light detection (Invited Paper) [10403-5]

1040307 Trace gas spectroscopy using state-of-the- art mid-infrared semiconductor laser sources: progress, status, and applications (Invited Paper) [10403-6]

1040308 Mid infrared DFB interband cascade lasers (Invited Paper) [10403-7]

1040309 A GaAs-based up-converter for mid-infrared detection utilizing quantum cascade transport [10403-8]

\section{SESSION 3 FOCAL PLANE TECHNOLOGY AND IMAGE PROCESSING}

10403 OA High bit depth infrared image compression via low bit depth codecs (Invited Paper) [10403-9]

$10403 \mathrm{OB}$ Observation and analysis of modulation and noise in visible and near infrared diffuse ambient daylight [10403-10]

10403 OC Flexible thermistors: MCNO films with low resistivity and high TCR deposited on flexible organic sheets by RF magnetron sputtering [10403-11]

10403 OD Nanoantenna integrated thermomechanical infrared pixels [10403-12] 
10403 OE Assessing the GOES-16 ABI solar channels calibration using deep convective clouds (Invited Paper) [10403-13]

10403 OF Preliminary study of the on-orbit radiometric traceability and artifacts for the VIIRS longwave infrared channels during blackbody temperature changes [10403-14]

10403 OG Millikelvin thermal dynamics of infrared scenes: sensitivity limits on optical detection of gas leaks [10403-15]

$10403 \mathrm{OH} \quad$ Utilizing the precessing orbit of TRMM to produce hourly corrections of geostationary infrared imager data with the VIRS sensor [10403-45]

SESSION $5 \quad$ PLANETARY AND COMET MISSIONS

10403 Ol Rosetta's studies of comet 67P's surface: a review after the end of the mission (Invited Paper) [10403-16]

10403 0J The Venus Emissivity Mapper concept (Invited Paper) [10403-17]

\section{SESSION $6 \quad$ MODELING INFRARED SYSTEMS AND PROCESSES}

10403 OL Directional ringlet intensity feature transform (DRIFT) based object tracking in IR imagery (Invited Paper) [10403-19]

1040300 Object parameters optimization on pure and mixed pixels in thermal hyperspectral imagery [10403-22]

SESSION 7 INSTRUMENTS, MISSIONS AND THEIR RETURNS

10403 OP Sentinel-5: the new generation European operational atmospheric chemistry mission in polar orbit (Invited Paper) [10403-23]

$104030 Q \quad$ Tissue characterization by trans-illumination interferometry [10403-30]

10403 OR Design and characterization of a low cost CubeSat multi-band optical receiver to map water ice on the lunar surface for the Lunar Flashlight mission [10403-25]

\section{SESSION 8 RECENT DEVELOPMENTS IN TERAHERTZ TECHNOLOGY}

10403 OS Millimeter-wave/terahertz detection and photonic double-mixing by transistors (Invited Paper) [10403-27]

10403 OT Generation of ultra-stable signal twins and idler twins by coupled optical parametric oscillators: applications in remote sensing (Invited Paper) [10403-28] 
10403 OU Thermal pulse propagation in the search of subcutaneous masses [10403-32]

10403 OV Noncoding sequence classification based on wavelet transform analysis: part I [10403-33]

10403 OW Optical spectral characterization of leaves for endemic species from La Primavera forest [10403-34]

10403 OY High precision phase-shifter modulator in a shearing interferometric system [10403-36]

$104030 Z$ Differential shearing interferometer [10403-37]

1040311 Forward and inverse solutions for Risley prism based on the Denavit-Hartenberg methodology [10403-39]

1040312 Three-dimensional shape profiling by projection of binary patterns: generated by a deterministic optimization approach [10403-40]

1040313 Online 3D measurement by an efficient iterative algorithm [10403-41]

1040314 Piezoresistive method for a laser induced shock wave detection on solids [10403-42]

1040317 Noncoding sequence classification based on wavelet transform analysis: part II [10403-46] 
Proc. of SPIE Vol. 10403 1040301-6

Downloaded From: https://www.spiedigitallibrary.org/conference-proceedings-of-spie on 26 Apr 2023 Terms of Use: https://www.spiedigitallibrary.org/terms-of-use 


\section{Authors}

Numbers in the index correspond to the last two digits of the seven-digit citation identifier (CID) article numbering system used in Proceedings of SPIE. The first five digits reflect the volume number. Base 36 numbering is employed for the last two digits and indicates the order of articles within the volume. Numbers start with 00, 01, 02, 03, 04, 05, 06, 07, 08, 09, OA, OB...0Z, followed by 10-12, 20-2Z, etc.

Arnold, Gabriele E., OI, OJ

Asari, Vijayan K., OL

Aspiras, Theus, $\mathrm{OL}$

Bader, Andreas, 06

Barragán, R. C., OW

Bartsch, Peter, OP

Bedka, Kristopher, $\mathrm{OH}$

Beltran-Gonzalez, A., 11

Belyaev, Evgeny, OA

Bhatt, Rajendra, $\mathrm{OH}$

Bi, Siwen, 03

Blonski, Slawomir, OF

Boerner, Anko, 0J

Bravo-Medina, Beethoven, $\mathrm{OZ}$

Cao, Changyong, OF

Chu, Junhao, OC

Clark, Frank O., OB

Crabtree, Karlton, OR

Cruz, Adan, 13

D'Amore, Mario, OJ

de la Fuente, Eduardo, $0 Z$

Ding, Yujie J., OT

Doelling, David R., $\mathrm{OH}$

Dyar, Darby, OJ

Emmerling, Monika, 06

Erdmann, Matthias, OP

Ferrari, Sabrina, 0J

Fischer, M., 08

Flores-Nuñez, J. L., OQ, OY, 11, 12, 13

Forchhammer, Søren, OA

Gao, Yanqing, OC

Garcia-Luna, J. L., 11

Garcia-Torales, Guillermo, 0Q, OV, OW, OY, 0Z, 11, $13,14,17$

Giglio, M., 07

Gomez Rosas, G., 14

González, Francisco Javier, OW

Gonzalez-Romero, R., 14

Gopalan, Arun, $\mathrm{OH}$

Griffin, R. J., 07

Guignan, Gabriel, 0J

Guzman, Brenda, $\mathrm{OQ}$

Hagen, Nathan, $0 G$

Han, Yanjun, 09

Haney, Conor, $\mathrm{OH}$

Hao, Zhibiao, 09

Hartmann, Fabian, 06

Hay, Jeffrey R., OB

Hayne, Paul O., OR
$\mathrm{He}$, Q., 07

Helbert, Joern, 0J

Höfling, Sven, 05, 06, 08

Hong, Pengda, OT

Huang, Zhiming, OC

lacovazzi, Robert, $\mathrm{OE}$

Jaenchen, Judit, OJ

Jensen, Elijah, OB

Jiang, Lin, $0 \mathrm{C}$

Kamp, Martin, 06, 08

Kappel, David, OJ

Kielkopf, John, OB

Knebl, Georg, 06

Koeth, J., 08

Kranjc, Tomaz, OU

Krieger, Evan, OL

Li, Hongtao, 09

Li, Junyu, OD

Lin, Xuling, 03

Liv, Huan, OD

Liu, Yaqi, 09

Luo, Yi, 09

Mantel, Claire, OA

Marca, Emmanuel, OJ

Martin, Didier, OP

Maturilli, Alessandro, 0J

Melf, Markus, OP

Miao, Xinyuan, 00

Minnis, Patrick, $\mathrm{OH}$

Morales, J. A., OV, 17

Mora-Nuñez, Azael, $0 Z$

Mueller, Nils, 0J

Muñoz, Antonio, 12, 13

Ordoñes, Sotero, 13

Otsuji, T., OS

Paine, Christopher G., OR

Paredes, O., OV, 17

Patimisco, P., 07

Pérez Albiñana, Abelardo, $\mathrm{OP}$

Pfenning, Andreas, 06

Qian, Haifeng, OE

Ranta, R., OV, 17

Reynoso-Alvarez, A., OY

Rodríguez-Rivas, Antonio, OW

Romo-Vázquez, R., 0V, 17

Sampaolo, A., 07

Sanchez, N. P., 07

Satou, A., OS

Scarino, Benjamin, $\mathrm{OH}$ 
Schade, Anne, 05, 08

Schevermann, J., 08

Scholl, Michelle K., OU, OV, 17

Seefelder, Wolfgang, OP

Sellar, Glenn R., OR

Silva, Adriana, 12

Smrekar, Suzanne, 0J

Spagnolo, V., 07

Strojnik, Marija, OQ, OU, OV, OW, OY, OZ, 11, 13, 14, 17

Sun, Changzheng, 09

Tan, Xiaochao, OD

Tittel, F. K., 07

Vélez-Pérez, H., OV, 17

Villa, Jesús, 12

Vinckier, Quentin, OR

Walter, Ingo, OJ

Wang, Chao, 09

Wang, Jian, 09

Wang, Lai, 09

Wang, Wenhui, OF

Weih, Robert, 06, 08

Wendler, Dennis, 0J

Widemann, Thomas, OJ

Worschech, Lukas, 06

Wright, Norrie, OP

Wu, Jing, OC

Wu, Xiangqian, $\mathrm{OE}$

Wu, Zhiqiang, 03

Xie, Lili, 09

Xiong, Bing, 09

Yang, Ao, OD

Yang, Kecheng, OD

Yang, Song, 03

Ye, W., 07

Yi, Fei, OD

Yoo, Hyelim, OE

Yu, Fangfang, OE

Zhang, Bin, OF

Zhang, Junping, 00

Zhang, Ye, 00

Zhen, Ming, 03

Zheng, $\mathrm{H}$., 07

Zhong, Shengwei, 00

Zhou, Wei, OC 


\section{Conference Committee}

Program Track Chair

Allen H.-L. Huang, University of Wisconsin-Madison (United States)

Conference Chairs

Marija Strojnik, Centro de Investigaciones en Óptica, A.C. (Mexico)

Maureen S. Kirk, Texas A\&M University (United States)

Conference Program Committee

Gabriele E. Arnold, Deutsches Zentrum für Luft- und Raumfahrt e.V. (Germany)

Gerald T. Fraser, National Institute of Standards and Technology (United States)

Guillermo Garcia-Torales, Universidad de Guadalajara (Mexico)

Sarath D. Gunapala, Jet Propulsion Laboratory (United States)

Sven Höfling, Julius-Maximilians-Universität Würzburg (Germany)

Pengda Hong, Lehigh University (United States)

Maureen L. Savage, SOFIA / USRA (United States)

Stanley J. Wellard, Space Dynamics Laboratory (United States)

Session Chairs

1 Emerging Infrared Technologies

Marija Strojnik, Centro de Investigaciones en Óptica, A.C. (Mexico)

2 Mid IR Sources and Detectors

Fabian Hartmann, Julius-Maximilians-Universität Würzburg (Germany) Guillermo Garcia-Torales, Universidad de Guadalajara (Mexico)

3 Focal Plane Technology and Image Processing

Maureen S. Kirk, Texas A\&M University (United States)

Guillermo Garcia-Torales, Universidad de Guadalajara (Mexico)

4 Infrared System Calibration and Performance Assessment

Marija Strojnik, Centro de Investigaciones en Óptica, A.C. (Mexico)

5 Planetary and Comet Missions

Marija Strojnik, Centro de Investigaciones en Óptica, A.C. (Mexico) 
6 Modeling Infrared Systems and Processes

Maureen S. Kirk, Texas A\&M University (United States)

Vijayan K. Asari, University of Dayton (United States)

7 Instruments, Missions and Their Returns

Maureen S. Kirk, Texas A\&M University (United States)

Marija Strojnik, Centro de Investigaciones en Óptica, A.C. (Mexico)

8 Recent Developments in Terahertz Technology

Guillermo Garcia-Torales, Universidad de Guadalajara (Mexico)

Abelardo Pérez Albiñana, European Space Research and Technology Center (Netherlands) 


\section{Introduction}

Once again, the conference on Infrared Remote Sensing and Instrumentation XXV took place in San Diego, California, 7-8 August 2017. It forms a part of the Symposium known as SPIE Optics + Photonics. The 26th conference in this series will be held next year, during the week of 19-26 August 2018.

Our conference celebrated its successful 25th anniversary this year. It is a quarter century, or equivalently in human time, one generation! This year, we added two new important committee members, Prof. Dr. Sven Höfling from Julius-Maximilians University, Germany, and Prof. Dr. Guillermo Garcia-Torales from The University of Guadalajara, Mexico. Dr. Höfling helped to expand the scope of the conference to include sources, emitters, and detectors in the mid-IR spectral range, the first session of the conference this year. Dr. Gracias-Torales was responsible for organizing a session on sensors and electro-optic devices, mostly concentrated in the Monday evening poster session. The conference also found it necessary to add a second chair, Dr. Maureen S. Kirk from Texas A \& M University, United States. We were fortunate indeed that Maureen joined us this year; she worked hard, coordinating activities from start to finish each day, and herself chairing sessions 3,6 and 7 .

The conference this year experienced an interesting advancement in terms of implementing further technological innovations. This year, SPIE introduced a more efficient technique of sequencing presentations. The speakers uploaded their talks two hours prior to the beginning of their session to the conference-wide network. In the conference room when the previous talk was finished, the title, authors and the presenter's name of the next presentation appear on the computer screen. This allowed the session chair to swiftly introduce and welcome the next speaker. This technological advancement lengthened the time of each presentation by about two minutes. Most of the time all presenters are so enthusiastic about delivering their reports, that they have to be advised to start winding down their talk. We are certain that most speakers have been appreciative of this innovation allowing them such extra time.

While many funding organizations and institutions of higher learning still favor oral presentations over the poster ones, we have always emphasized the sort of the exchange of information that is only possible in a poster session. Since a large number of authors at this conference preferred to present their research as a poster, we were able to observe an increased amount of communication between the authors and the interested participants. Contrast this with the oral presentations, where the authors must adhere to the scheduled time. During posters, the dialog may take the requisite time that it takes to exchange information of mutual interest. 
The duration of the conference during the last decade has stabilized at two days. This year, the conference included 39 presentations, with some speakers preferring to present their work more conveniently in a poster format. Thirty-three presenters prepared their reports in time for the inclusion for the publication in these Proceedings.

Over the years, our conference has established itself as an instrumentation conference, bringing back scientists and engineers to report on significant developments within their areas of expertise. This year we had eight sessions dealing with diverse missions and technological development in support of future missions. We consider ourselves very fortunate to have such conscientious contributors.

We wish to express our appreciation to the chairs, authors, presenters, and the audience for providing such an interesting, lively, and stimulating technical exchanges. There were always more questions than the time allotted, and the conversations would extend into the breaks and visits to the exhibition. Technical interchanges will continue also through e-mail, and during the next-year's conference, 19-26 August 2018.

Special thanks to the SPIE staff who work first to organize everything in support of the conference assuring that it runs smoothly, and for preparing the proceedings so that papers are published on the SPIE Digital Library website within a few short weeks after the conference. This makes the papers available to the worldwide audience in a timely fashion.

On behalf of several students, we also wish to express our gratitude to the SPIE for offering the student travel grant program. Without it, they would not have been able to present their important research, marking the beginning of their research career.

\section{Marija Strojnik Maureen S. Kirk}

